\title{
Pengaruh Pembelajaran dengan Pendekatan Kontekstual Terhadap Kemampuan Memecahkan Masalah Fisika Pada Siswa Kelas X SMA Al-Azhar Palu
}

\author{
Siti Maemanah, I Komang Werdhiana dan Jusman Mansyur \\ e-mail: sitimaemanah@gmail.com \\ Program Studi Pendidikan Fisika FKIP Universitas Tadulako \\ Jl. Soekarno Hatta Km. 9 Kampus Bumi Tadulako Tondo Palu - Sulawesi Tengah
}

\begin{abstract}
Abstrak - Penelitian ini bertujuan mengetahui ada tidaknya pengaruh Pembelajaran dengan Pendekatan Kontekstual Terhadap Kemampuan Memecahkan Masalah Fisika Pada Siswa Kelas X SMA Al-Azhar Palu. Desain penelitian adalah the non equivalen pretest-posttest design. Populasi penelitian adalah seluruh siswa kelas $\mathrm{X}$ pada SMA Al-Azhar Palu. Pengambilan sampel dilakukan secara purposive sampling dengan sampel penelitian adalah kelas $X_{C}(n=19)$ sebagai kelas eksperimen dan Kelas $X_{D}(n=18)$ sebagai kelas kontrol. Instrumen penelitian adalah tes kemampuan memecahkan masalah dan lembar observasi. Pengujian hipotesis dilakukan dengan menggunakan statistik nonparametrik dengan uji Mann-Whitney $U$ pada taraf signifikan 0,05. Hasil penelitian menunjukkan bahwa terdapat pengaruh pembelajaran dengan pendekatan kontekstual terhadap kemampuan memecahkan masalah fisika pada siswa kelas X SMA Al-Azhar Palu.
\end{abstract}

Kata Kunci: pendekatan kontekstual, kemampuan memecahkan masalah

\section{PENDAHULUAN}

Kemampuan memecahkan masalah merupakan salah satu tujuan dalam pembelajaran fisika. Melalui kemampuan memecahkan masalah, hasil belajar diharapkan menjadi lebih bermakna bagi siswa, serta hasil dari proses pembelajaran tersebut dapat digunakan oleh siswa dalam konteks kehidupan nyata. Proses pembelajaran harus melibatkan para siswa dalam pencarian makna dan memungkinkan para siswa memahami arti pelajaran yang mereka pelajari sehingga siswa dapat mengaktualisasikannya dalam kehidupan sehari-hari mereka[1].

Guru atau pendidik sebagai pelaku perubahan harus mampu menyusun dan merancang sebuah pembelajaran yang memudahkan siswa untuk memahami, menemukan makna dan menghubungkan pelajaran yang mereka pelajari dengan keadaan lingkungan mereka. Pengaruh lingkungan lebih besar daripada yang kita bayangkan. Otak anak yang menghabiskan banyak waktu untuk menonton televisi sangat berbeda strukturnya dengan otak anak yang sering berbicara dengan orang dewasa[1]. Berdasarkan hal tersebut, penulis memilih pembelajaran dengan pendekatan kontekstual.

Pembelajaran kontekstual merupakan pembelajaran yang mengkaitkan materi pembelajaran dengan konteks dunia nyata yang dihadapi siswa sehari-hari baik dalam lingkungan keluarga, masyarakat, alam sekitar dan dunia kerja, sehingga siswa mampu membuat hubungan antara pengetahuan yang dimilikinya dengan penerapannya dalam kehidupan sehari-hari, dengan melibatkan tujuh komponen utama pembelajaran yakni: kontruktivisme, bertanya, menyelidiki, masyarakat belajar, pemodelan, refleksi, dan penilaian autentik[2].

Pembelajaran dengan pendekatan kontekstual berpengaruh pada anggapan siswa tentang fisika yang menganggap fisika sulit dan setelah pembelajaran dengan pendekatan kontekstual siswa beranggapan fisika itu menyenangkan[3].

Berdasarkan uraian di atas, peneliti bermaksud untuk mengetahui pengaruh pembelajaran dengan pendekatan kontekstual terhadap kemampuan memecahkan masalah fisika pada siswa Kelas X SMA Al-azhar Palu.

\section{METODE PENELITIAN}

Jenis penelitian yang digunakan adalah jenis penelitian dengan rancangan eksperimen kuasi (quasi-experimental design)

Desain penelitian yang digunakan yaitu the non eqivalent pretest-posttest design. 
Desain penelitian yang digunakan dapat dilukiskan seperti pada Tabel 1.

Tabel 1 Rancangan Prates-Pascates yang tidak Equivalent

\begin{tabular}{|l|c|c|c|}
\hline \multicolumn{1}{|c|}{ Kelompok } & Prates & Perlakuan & Pascates \\
\hline Eksperimen & $\mathrm{O}$ & $\mathrm{X}$ & $\mathrm{O}$ \\
\hline Kontrol & $\mathrm{O}$ & - & $\mathrm{O}$ \\
\hline
\end{tabular}

\section{Keterangan:}

$\mathrm{X}$ : Perlakuan dengan pendekatan kontekstual 0 : Prates/Pascates

Penelitian dilakukan di SMA Al-Azhar Palu. Populasi dalam penelitian ini adalah seluruh siswa kelas $X$ SMA A-Azhar Palu tahun pelajaran 2015/2016 yang terdiri dari 4 kelas. Sampel dalam penelitian ini adalah kelas XC dan XD. Teknik pengumpulan sampel yang digunakan adalah purposive sampling, yaitu teknik penentuan sampel dengan pertimbangan tertentu.

\section{INSTRUMEN PENELITIAN}

Instrumen yang digunakan dalam penelitian ini adalah tes kemampuan memecahkan masalah siswa yang berupa soal essai berjumlah 7 nomor dan lembar observasi untuk mengamati kegiatan guru dan siswa

\section{TEKNIK ANALISA DATA}

Data pada penelitian dihitung menggunakan ujin $\mathrm{N}$-Gain untuk melihat peningkatan kemampuan siswa memecahkan masalah dan uji hipotesis nonparametrik Mann Whitney U.

\section{HASIL DAN PEMBAHASAN}

1. Hasil Penelitian

A. Uji Peningkatan Kemampuan Memecahkan

Masalah tentang Hukum Newton

Peningkatan kemampuan memecahkan masalah siswa tentang hukum Newton yang diperoleh dari kelas eksperimen (menggunakan pendekatan kontekstual) dan kelas kontrol (menggunakan pembelajaran konvensional) yang dihitung menggunakan persamaan $\mathrm{N}$-Gain disajikan pada Tabel 2.
Tabel 2 Hasil Uji N-Gain Kelas Eksperimen dan KelasKontrol

\begin{tabular}{|l|c|c|c|c|}
\hline Uraian & $\begin{array}{c}\text { Pretest } \\
(\%)\end{array}$ & $\begin{array}{c}\text { Posttest } \\
(\%)\end{array}$ & $\begin{array}{c}\text { N-Gain } \\
(\%)\end{array}$ & Kategori \\
\hline $\begin{array}{l}\text { Kelas } \\
\text { Eksperimen }\end{array}$ & 15,37 & 27,79 & 36,32 & Sedang \\
\hline $\begin{array}{l}\text { Kelas } \\
\text { Kontrol }\end{array}$ & 10,67 & 20,11 & 24,57 & Rendah \\
\hline
\end{tabular}

Berdasarkan Tabel 2 dapat dilihat bahwa peningkatan kemampuan memecahkan masalah siswa untuk kelas eksperimen berada pada ketegori sedang dan untuk kelas kontrol berada pada ketegori rendah. Jika ditinjau secara kuantitatif untuk kelas eksperimen lebih unggul dari kelas kontrol dengan nilai rata-rata $\mathrm{N}$-Gain sebesar $36,32 \%$ sedangkan untuk kelas kontrol 24,57\%.

Data tersebut disajikan kembali dalam histogram agar lebih memberikan gambaran detail dan menyeluruh tentang hasil penelitian.

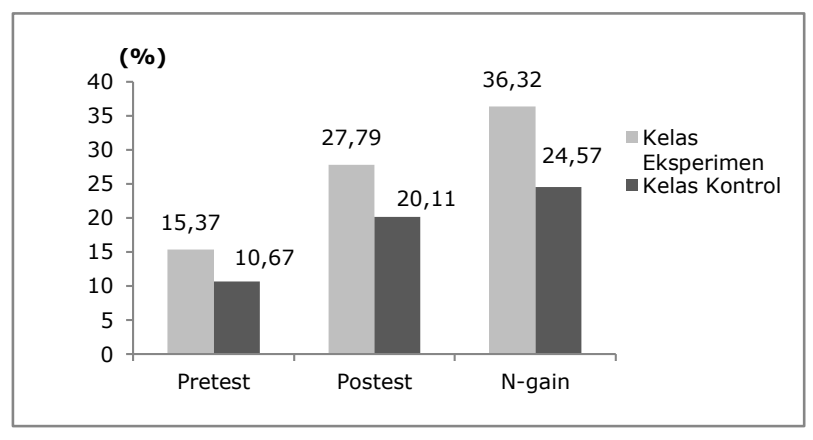

Gambar 1 Diagram Perbandingan Skor Rata-rata Tes awal, Tes akhir dan N-gain Tes Pemahaman Konsep antara Kelas Eksperimen dan Kelas Kontrol

B. Uji Hipotesis

Uji hipotesis ini digunakan untuk memastikan apakah hipotesis yang diajukan dapat diterima atau ditolak. Uji hipotesis ini menggunakan uji statistik nonparametrik uji Mann-Whitney U. Hal ini disebabkan karena pada penelitian ini digunakan dua kelas yang independen.

Tabel 3 Uji Hipotesis Kelas Eksperimen dan Kelas Kontrol

\begin{tabular}{|c|c|c|c|c|}
\hline Kelas & $\overline{\mathrm{X}}$ & $U_{\text {hitung }}$ & $\begin{array}{c}\mathrm{U}_{\text {tabel }} \\
(\alpha=0,05)\end{array}$ & Keputusan \\
\hline Eksperimen & 36,32 & \multirow{2}{*}{89,00} & \multirow{2}{*}{116,00} & \multirow{2}{*}{$\mathrm{H}_{\mathrm{o}}$ ditolak } \\
\hline Kontrol & 24,57 & & & \\
\hline
\end{tabular}

Berdasarkan Tabel 3 Nilai $U_{\text {hitung }}<U_{\text {tabel }}$ atau $89,00<116,00$. Hal ini menunjukkan bahwa $U_{\text {hitung }}$ berada diluar daerah penerimaan Ho. Dengan demikian dapat disimpulkan bahwa 
rata-rata kemampuan memecahkan masalah siswa yang mendapatkan pembelajaran dengan pendekatan kontekstual lebih baik daripada siswa yang mendapatkan pembelajaran konvensional sehingga dapat dikatakan terdapat pengaruh pembelajaran kontekstual terhadap kemampuan memecahkan masalah pada siswa.

\section{Hasil Observasi}

Data aktivitas guru dan siswa diperoleh melalui observasi yang dilakukan oleh seorang observer setiap pertemuan menggunakan lembar observasi. Hasil observasi aktivitas guru dan siswa pada kelas eksperimen dan kontrol dapat dilihat pada Tabel 4 dan Tabel 5.

Tabel 4 Hasil Observasi Aktivitas Guru dan Siswa Kelas Eksperimen

\begin{tabular}{|c|c|c|}
\hline Pertemuan & $\begin{array}{c}\text { Rerata Skor (\%) } \\
\text { Siswa }\end{array}$ & $\begin{array}{c}\text { Rerata Skor (\%) } \\
\text { Guru }\end{array}$ \\
\hline Pertemuan 1 & 80,15 & 85,29 \\
\hline Pertemuan 2 & 83,82 & 86,03 \\
\hline Pertemuan 3 & 85,29 & 86,76 \\
\hline $\begin{array}{c}\text { Rerata skor } \\
(\%)\end{array}$ & 83,09 & 86,03 \\
\hline
\end{tabular}

Tabel 5 Hasil Observasi Aktivitas Guru dan Siswa Kelas Kontrol

\begin{tabular}{|c|c|c|}
\hline Pertemuan & $\begin{array}{c}\text { Rerata Skor (\%) } \\
\text { Siswa }\end{array}$ & $\begin{array}{c}\text { Rerata Skor } \\
(\%) \\
\text { Guru }\end{array}$ \\
\hline Pertemuan 1 & 70,00 & 83,82 \\
\hline Pertemuan 2 & 76,66 & 80,88 \\
\hline Pertemuan 3 & 78,33 & 83,82 \\
\hline Rerata skor (\%) & 74,99 & 82,84 \\
\hline
\end{tabular}

Berdasarkan Tabel 4 dan Tabel 5, dapat dilihat persentase aktivitas guru dan siswa pada kelompok eksperimen lebih tinggi daripada kelas kontrol.

\section{Jawaban Hasil Tes}

Untuk mengetahui gambaran kemampuan memecahkan masalah siswa dalam penelitian digunakan instrumen penelitian berupa tes sejumlah 7 butir soal essai. Berikut ditampilkan beberapa kutipan jawaban siswa pada kelas eksperimen dengan pendekatan kontekstual tentang Hukum Newton untuk melihat kemampuan memecahkan masalah pada siswa melalui tes pemecahan masalah. Siswa yang dijadikan responden dapat dilihat pada Tabel 6 .
Tabel 6 Hasil Observasi Aktivitas Guru dan Siswa Kelas Eksperimen

\begin{tabular}{|c|c|c|}
\hline No & Kode Responden & Kategori \\
\hline 1 & R-16 & Sedang \\
\hline 2 & R-03 & Sedang \\
\hline 3 & R-04 & Sedang \\
\hline 4 & R-14 & Sedang \\
\hline 5 & R-01 & Sedang \\
\hline 6 & R-02 & Sedang \\
\hline 7 & R-10 & Sedang \\
\hline
\end{tabular}

a) Soal tentang Konsep Hukum I Newton (1)

Soal yang diberikan tentang sebuah koin yang diletakkan di atas meja kemudian kertas tersebut ditarik. Siswa diminta untuk menjelaskan apa yang terjadi pada koin tersebut (Lampiran A soal No.1). Untuk lebih jelasnya, kemampuan memecahkan masalah R16 mengenai Hukum I Newton dapat dilihat pada Tabel 7.

Tabel 7 Perbandingan jawaban pretest dan posttest R-16

\begin{tabular}{|c|c|}
\hline & Jawaban siswa \\
\hline Pretest & 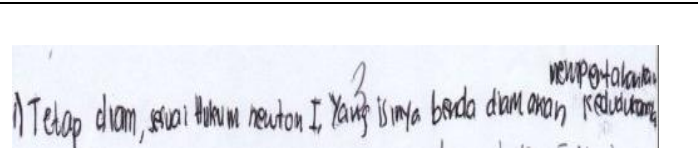 \\
\hline Posttest & 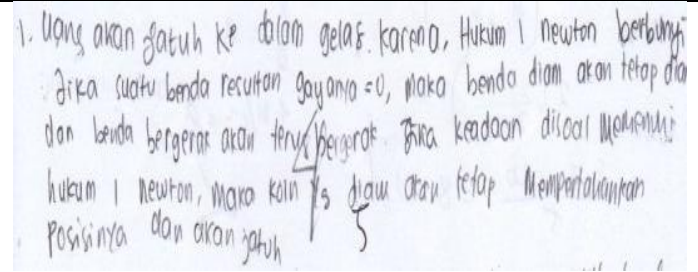 \\
\hline
\end{tabular}

b) Soal tentang Konsep Hukum II Newton (2)

Soal yang diberikan tentang sebuah kotak yang ditarik. Siswa diminta untuk menentukan jarak tempuh kotak dalam waktu tertentu (Lampiran A soal No.2). Untuk lebih jelasnya, kemampuan memecahkan masalah R-03 dapat dilihat pada Tabel 8. 
Tabel 8 Perbandingan jawaban pretest dan posttest R-03

\begin{tabular}{|c|c|}
\hline & Jawaban siswa \\
\hline Pretest & $\begin{array}{l}\text { 2. Dik. massa kotak } 10 \mathrm{~kg} \text { ditarik dgh gaya } 100 \mathrm{~N} \\
\text { gaya penghambat trotak. } 25 \mathrm{~N} \\
\text { Dit, jarak yos ditempun setelah } 10 \mathrm{~s} \text {. } \\
\text { Peny. }\end{array}$ \\
\hline Posttest & 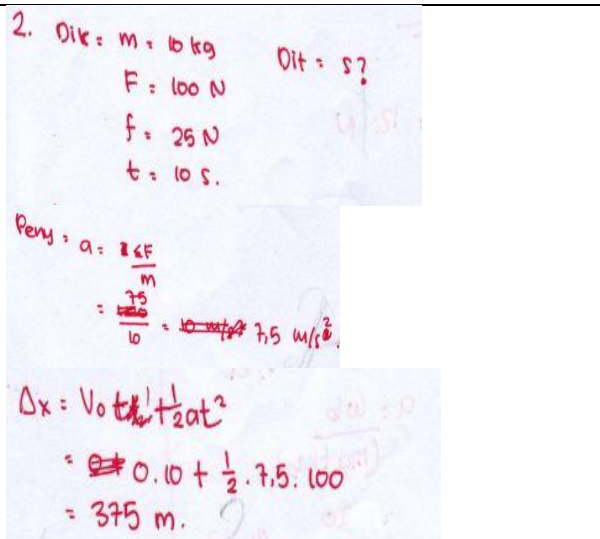 \\
\hline
\end{tabular}

c) Soal tentang Konsep Hukum I Newton (3)

Soal yang diberikan tentang sebuah bis yang sedang berjalan dan tiba-tiba supir bis menginjak rem secara mendadak. Siswa diminta untuk menyebutkan apa yang terjadi dan menjelaskan (Lampiran A soal No.3). Untuk lebih jelasnya, kemampuan memecahkan masalah R-04 mengenai Hukum I Newton dapat dilihat pada Tabel 9.

Tabel 9 Perbandingan jawaban pretest dan posttest R-03

\begin{tabular}{|c|c|}
\hline & Jawaban Siswa \\
\hline Pretest & 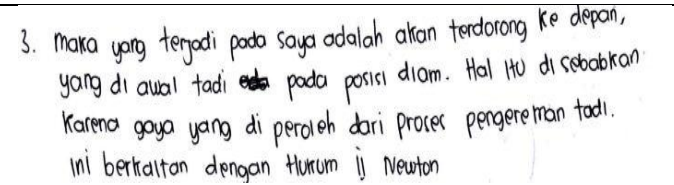 \\
\hline Posttest & 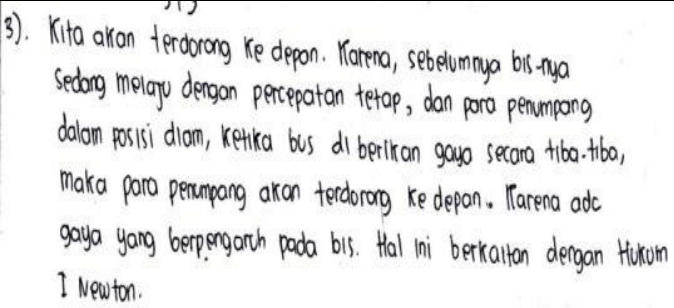 \\
\hline
\end{tabular}

d) Soal tentang Konsep Hukum II Newton

Soal yang diberikan tentang sebuah boal yang dilemparkan vertikal ke atas. Siswa diminta untuk menghitung kelajuan awal dan ketinggian maksimum bola (Lampiran $A$ soal No.4). Untuk lebih jelasnya, kemampuan memecahkan masalah R-14 tentang Hukum II Newton dapat dilihat pada Tabel 10.

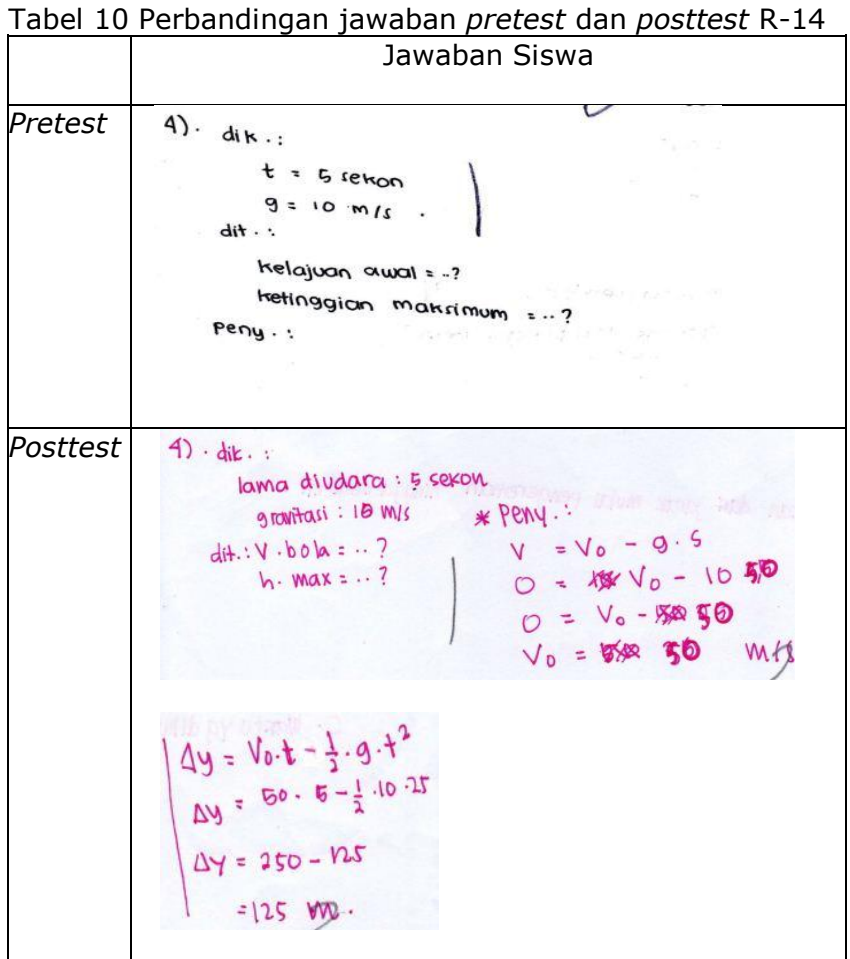

e) Soal tentang Konsep Hukum III Newton

Soal pada Nomor ini disajikan sebuah gambar kemudian siswa diminta untuk menjelaskan tentang gambar tersebut (Lampiran A soal No.5). Untuk lebih jelasnya, kemampuan memecahkan masalah R-01 mengenai Hukum III Newton dapat dilihat pada Tabel 11.

Tabel 11 Perbandingan jawaban pretest dan posttest R-01

\begin{tabular}{|c|c|}
\hline & Jawaban Siswa \\
\hline Pretest & 5.) e. Hulum II Neution \\
\hline Posttest & 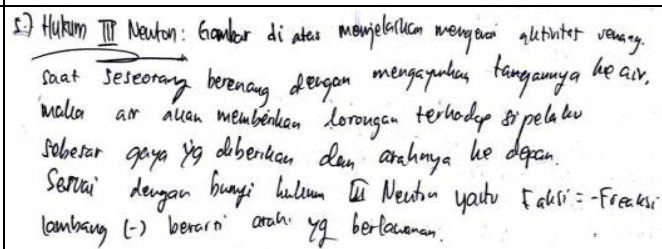 \\
\hline
\end{tabular}

f) Soal tentang Konsep Hukum II dan Hukum III Newton

Soal pada Nomor ini disajikan sebuah gambar. Siswa diminta untuk menghitung percepatan dan besar gaya tegangan tali (Lampiran A soal No.6). Untuk lebih jelasnya, kemampuan memecahkan masalah R-02 
mengenai konsep Hukum II dapat dilihat pada Tabel 12.

\begin{tabular}{|c|c|}
\hline & Jawaban Siswa \\
\hline Pretest & $\begin{aligned} \text { 6u. biK: } \begin{aligned} m_{a} & =3 \mathrm{~kg} \\
M_{b} & =2 \mathrm{~kg} \\
g & =10 \mathrm{~m} / \mathrm{s}^{2}\end{aligned} \\
\text { DIt: percepatan benda \& tegangan tali }\end{aligned}$ \\
\hline Posttest & 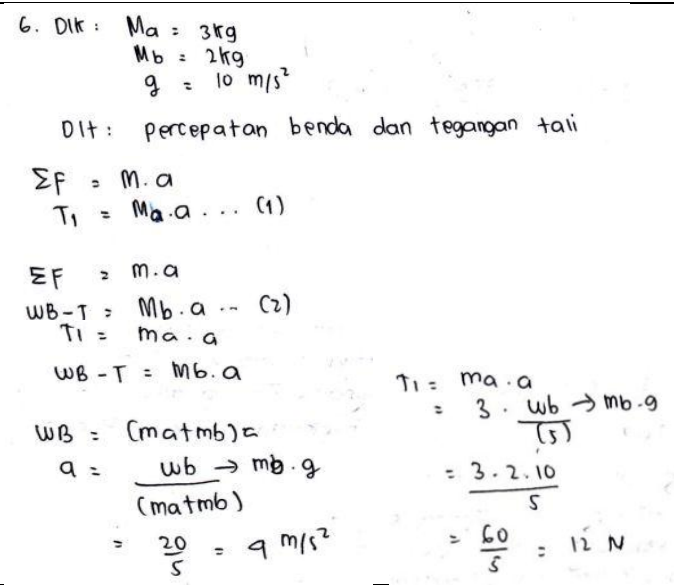 \\
\hline
\end{tabular}

g) Soal tentang Konsep Hukum II dan Hukum III Newton

Soal yang diberikan tentang seorang anak yang sedang mendorong mobil-mobilan dilantai kasar. Siswa diminta untuk menghitung percepatan, kecepatan awal dan waktu yang dibutuhkan menempuh jarak tertentu (Lampiran A soal No. 7). Untuk lebih jelasnya, kemampuan memecahkan masalah R-10 tentang Hukum II Newton dapat dilihat pada Tabel 13.

Tabel 13 Perbandingan jawaban pretest dan posttest R-10

\begin{tabular}{|c|c|}
\hline & Jawaban Siswa \\
\hline Pretest & 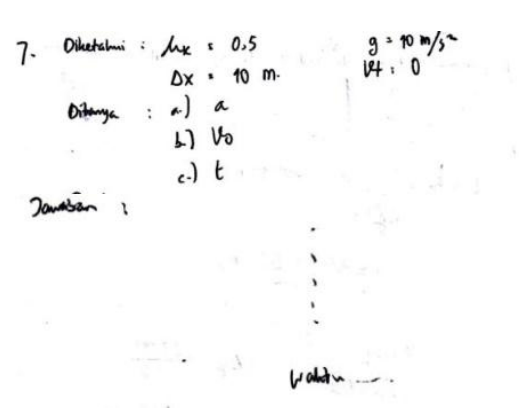 \\
\hline Posttest & 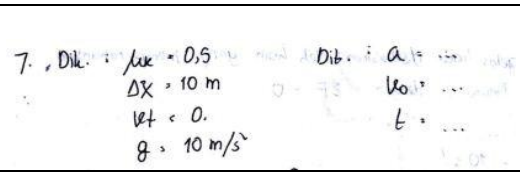 \\
\hline
\end{tabular}

\begin{tabular}{|c|}
\hline 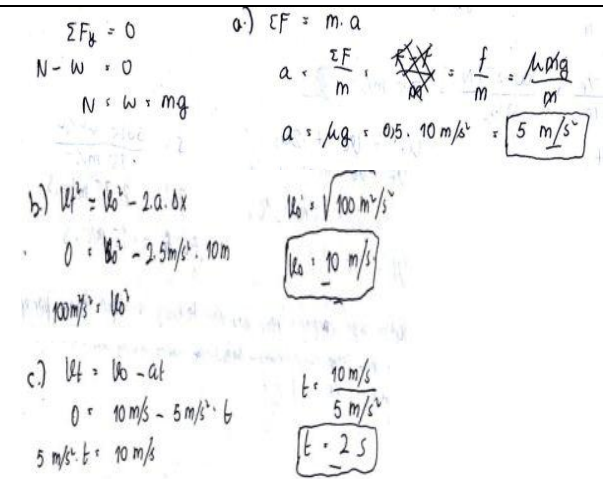 \\
\hline
\end{tabular}

\section{Pembahasan}

Sebelum diberikan perlakuan, siswa pada kelas eksperimen dan kelas kontrol diberikan tes awal untuk mengetahui kemampuan awal siswa. Selanjutnya, siswa yang berada di kelas eksperimen menerima materi Hukum Newton dengan pembelajaran menggunakan pendekatan kontekstual, sedangkan siswa pada kelas kontrol menerima materi dengan pembelajaran konvensional. Selanjutnya kedua kelas tersebut diberikan tes akhir untuk melihat pengaruh pembelajaran dengan pendekatan kontekstual terhadap kemampuan memecahkan masalah fisika pada siswa.

Pada saat dilakukan tes akhir diperoleh skor rata-rata seperti pada Gambar 1 yaitu untuk kelas eksperimen sebesar 27,79\% dengan $\mathrm{N}$-gain $36,32 \%$ dan kelas kontrol sebesar $20,11 \%$ dengan $\mathrm{N}$-gain sebesar 24,57\%. Dari skor $\mathrm{N}$-gain tersebut ditunjukkan bahwa kelas eksperimen yang menerima materi dengan pendekatan kontesktual memperoleh peningkatan kemampuan memecahkan masalah lebih tinggi daripada kelas kontrol yang menerima materi dengan pembelajaran konvensional.

Selama dalam pembelajaran siswa dalam kelompok-kelompok kecil setiap kelompok terdiri dari empat atau lima siswa dan anggota kelompok sifatnya tetap. Dengan mengelompokkan siswa ke dalam kelompokkelompok kecil, memberi peluang untuk mendiskusikan masalah yang dihadapi, saling tukar ide antar siswa, dan memperdebatkan alternatif pemecahan masalah. Selain itu, siswa dimungkinkan mampu menyelesaikan masalah yang lebih baik dibanding jika mereka bekerja sendiri [4].

Pada pembelajaran dengan pendekatan kontekstual memiliki tahapan-tahapan. Tahap pertama yaitu tahap contruktivisme (kontruktivisme). Tahap ini bertujuan mengembangkan pemikiran siswa untuk 
melakukan kegiatan belajar lebih bermakna apakah dengan cara bekerja sendiri, menemukan sendiri, dan mengonstruksi sendiri pengetahuan dan keterampilan baru yang harus dimilikinya. Untuk merangsang pengetahuan awal siswa guru memberikan pertanyaan yang berhubungan dengan kehidupan sehari-hari. Pada tahap ini siswa akan mulai aktif dalam menjawab pertanyaan dan mencari tahu sendiri jawaban dari pertanyaan tersebut. Dengan mengkontruksi sendiri pikirannya maka siswa akan mandiri dan termotivasi untuk bisa menemukan jawaban sendiri. Hal ini sesuai dengan hasil penelitian sebelumnya yang menyatakan bahwa dengan mengkontruksi konsep-konsep fisika melalui pengalamannya sendiri akan membuat siswa mandiri, punya inisiatif untuk selalu ingin tahu dan ingin mencoba menemukan berbagai alternatif jawaban melalui sumber yang ada disekitarnya[5].

Selanjutnya tahap modeling (pemodelan), pada tahap ini guru meminta siswa untuk memperagakan contoh dalam kehidupan nyata tentang materi yang dipelajari. Misalnya untuk hukum III Newton, salah satu siswa diminta untuk mendorong tembok kemudian siswa lain akan mengamati dan menganalisis konsep hukum III Newton dalam pemodelan tersebut. Dengan adanya pemodelan tersebut siswa dapat lebih mudah memahami materi yang diajarkan. Hasil ini sesuai dengan penelitian sebelumnya yaitu melalui peragaan-peragaan (modeling) yang dapat ditiru oleh setiap siswa sehingga konsep pembelajaran yang ditemukan menjadi terarah dan mudah tercapai[6].

Pada tahap ketiga yaitu community learning (masyarakat belajar), siswa berkelompok untuk melakukan eksperimen. Setelah melakukan eksperimen aktivitas siswa meningkat karena pada tahap ini siswa sendiri yang melakukan kegiatan sesuai dengan LKS yang dibagikan oleh guru. Dengan meningkatnya aktivitas siswa maka motivasi belajar siswa meningkat dan menghasilkan pembelajaran yang lebih baik. Hasil ini sesuai dengan penelitian sebelumnya yaitu kelompok yang melakukan pengamatan melalui eksperimen hasilnya lebih baik dari kelompok yang menerima materi dari gambar karena melalui eksperimen siswa terlibat langsung dalam kegiatan untuk menemukan suatu konsep dan melibatkan lebih banyak indera. Kemudian dilanjutkan menyelesaikan permasalahan yang terdapat didalam Lembar Kerja Siswa (LKS)[7].
Pada tahap keempat yaitu tahap questioning (bertanya), guru memberikan kesempatan siswa untuk bertanya apabila mengalami kesulitan dalam menyelesaikan LKS. Selain itu, pada tahap ini siswa juga diberi kesempatan untuk mempresentasikan hasil diskusi kelompok dan diberikan kesempatan untuk saling bertanya, bertukar pendapat dengan kelompok lain terkait dengan materi. Dengan bertanya menunjukkan bahwa siswa berani mengajukan pendapat. Hal ini sesuai dengan penelitian sebelumnya yang menjelaskan bahwa implementasi pembelajaran kontekstual membuat siswa lebih berani mengemukakan pendapat maupun mengajukan pertanyaan[8].

Pada tahap yang kelima yaitu inquiry (menemukan) yang bertujuan agar siswa dapat menemukan sendiri cara menyelesaikan masalah yang diberikan. Pengetahuan dan keterampilan yang diperoleh siswa diharapkan bukan hasil mengingat seperangkat fakta-fakta, tetapi hasil dari menemukan sendiri. Pada tahap ini guru memberikan pertanyaan kepada siswa. Siswa akan lebih mudah dalam menjawab pertanyaan dan memecahkan masalah karena mereka telah memahami sendiri konsep tersebut. Hal ini sesuai dengan hasil penelitian sebelumnya yang menyatakan bahwa dengan menemukan sendiri kebenaran dari konsep itu sehingga siswa lebih memahami dan lebih ingat mengenai konsep tersebut serta mampu memperbaiki miskonsepsi yang dimilikinya[6].

Pada tahap keenam yaitu reflection (refleksi), guru meminta siswa untuk menyimpulkan kembali isi materi yang telah dipelajari kemudian menghubungkannya dengan kehidupan sehari-hari, sehingga siswa akan merasa memperoleh sesuatu yang berguna bagi dirinya tentang apa yang baru dipelajarinya dan memberikan penghargaan bagi kelompok terbaik. Misalnya pada Hukum I Newton siswa menyimpulkan bunyi Hukum I Newton yaitu "jika resultan gaya pada suatu benda sama dengan nol, maka benda yang mula-mula diam akan terus bergerak dengan kecepatan tetap", kemudian menyebutkan contohnya dalam kehidupan sehari-hari, misalnya seseorang berada dalam sebuah mobil yang sedang melaju secara tiba-tiba mobil tersebut direm, maka badan orang tersebut pasti akan terdorong ke depan karena orang tersebut cenderung untuk mempertahankan keadaan awalnya. 
Tahap yang terakhir adalah tahap authentic assesment (penilaian sebenarnya), pada tahap ini guru menilai selama proses pembelajaran. Pada penilaian proses ini guru akan menilai beberapa aspek yang dilakukan siswa selama proses pembelajaran seperti keaktifan siswa dalam pembelajaran, keterampilan siswa dalam melakukan praktikum ataupun dalam menjawab pertanyaan dan bagaimana kerjasama siswa dalam kelompok.

Setelah diterapkan pembelajaran dengan pendekatan kontekstual diperoleh hasil penelitian yang menunjukkan bahwa kelas tersebut mengalami peningkatan kemampuan memecahkan masalah dapat dilihat pada Gambar 2.

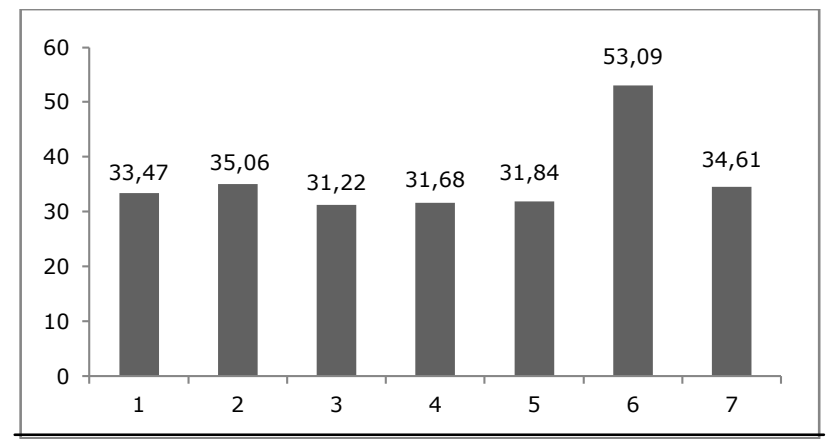

Gambar 2 Rerata N-gain tiap butir soal

Berbeda halnya dengan kelas eksperimen, pada kelas kontrol proses pembelajarannya menggunakan pembelajaran konvensional yaitu ceramah dan tanya jawab. Pada pembelajaran ini siswa cenderung bersifat pasif, hanya menerima semua yanng dijelaskan oleh guru dan mencatat hal-hal yang dianggap penting di papan tulis. Sementara kegiatan guru adalah menyampaikan materi hukum Newton secara lisan. Selain itu ketika siswa diberikan kesempatan untuk mengajukan pertanyaan, mereka canggung untuk bertanya. Ketidak aktifan siswa dalam proses pembelajaran menyebabkan siswa kurang termotivasi untuk menemukan konsep terkait dengan materi yang diberikan. Selain itu, menyebabkan materi yang diterima kurang efektif sehingga mudah terlupakan dan pada akhirnya kemampuan memecahkan masalah siswa kurang berkembang.

Kelebihan dari pembelajaran dengan pendekatan kontekstual dibandingkan dengan pembelajaran konvensional adalah pembelajaran yang menyenangkan dan keaktifan siswa. Karena pembelajaran dengan pendekatan kontekstual akan mempengaruhi cara berfikir siswa terhadap pembelajaran fisika sesuai dengan penelitian sebelumnya menyatakan bahwa pendekatan kontekstual berpengaruh pada anggapan siswa tentang fisika yang menganggap fisika sulit dan setelah pembelajaran dengan pendekatan kontekstual siswa beranggapan fisika itu menyenangkan[3].

Berdasarkan analisis data yang dilakukan, penelitian menunjukkan bahwa terdapat pengaruh pembelajaran dengan menggunakan pendekatan kontekstual terhadap kemampuan memecahkan masalah fisika siswa. Hasil yang diperoleh didukung oleh hasil penelitian sebelumnya yang bertujuan untuk mengidentifikasi ada tidaknya pengaruh pembelajaran kontekstual terhadap pemahaman siswa dalam konsep bunyi. Berdasarkan hasil data analisis penelitian menunjukkan bahwa terdapat pengaruh yang signifikan pembelajaran kontekstual terhadap pemahaman konsep siswa pada bunyi[9].

\section{KESIMPULAN}

Berdasarkan hasil dan analisis data penelitian maka dapat disimpulkan bahwa terdapat pengaruh pembelajaran dengan pendekatan kontekstual terhadap kemampuan memecahkan fisika pada siswa kelas X SMA AlAzhar Palu.

\section{DAFTAR PUSTAKA}

[1] Johnson, E.B. (2011). CTL (Cotntextual Teaching and Learning). Bandung: Kaifa.

[2] Jumadi. (2003) . Pembelajaran Kontekstual dan Implementasinya. Makalah pada workshop sosialisasi dan implementasi kurikulum 2004 Madrasah Aliyah DIY, Jateng, Kalsel di FMIPA UNY.

[3] Tural, G. (2013). The functioning of context-based pysics instruction in higher education. Asia-pacific forum on science learning and teaching. Vol 14, 21 halaman.Tersedia:http://www.ied.edu.hk/apfslt/dow nload/v14_issue1_files/tural.pdf/[20 januari 2015].

[4] Erman, S. (2003). Strategi Pembelajaran Matematika Komtemporer. Bandung: JICA-UPI.

[5] Murniati, Fauzan, A., dan Wulan, R. (2012). Penerapan Pendekatan CTL berbasis Lesson Study dalam meningkatkan kualitas pembelajaran Fisika di SMP Negeri Kota Padang. Jurnal Penelitian Pembelajaran Fisika. (1):1-21.

[6] Suniati, M.S., Sadia,W., dan Suhandana, A. (2013). "Pengaruh Implementasi Pembelajaran Kontekstual Berbantuan Multimedia Interaktif Terhadap Penurunan Miskonsepsi". E-Journal Program Pascasarjana Universitas Pendidikan Ganesha. Vol 4: $1-13$.

[7] Nurjannah, F. (2014). Analisis Kemampuan Generik Siswa Melalui Kegiatan Praktikum Fotosintesis (Penelitian Deskriptif pada Kelas VIII di SMP AL- 
Hasra Depok). Skripsi pada Fakultas Ilmu Tarbiyah dan Keguruan UIN Syarif Hidayatullah. Jakarta: Tidak dipublikasikan.

[8] Gita, I.N. (2007). Implementasi Pendekatan Konekstual Untuk Meningkatkan Prestasi Belajar Matematika Siswa di Sekolah Dasar. Jurnal Penelitian dan Pengembangan Pendidikan.1(1): 2634.

[9] Mardianti, L. (2011). Pengaruh Pembelajaran Kontekstual terhadap Pemahaman Konsep Bunyi. Skripsi pada Fakultas Ilmu Tarbiyah dan Keguruan UIN Syarif Hidayatullah. Jakarta: Tidak dipublikasikan. 


\section{LAMPIRAN A}

TES KEMAMPUAN MEMECAHKAN MASALAH

1. Koin uang logam yang diletakkan di atas selembar kertas pada gelas kaca. Kemudian diletakkan di atas meja. Ujung kertas lainnya ditarik dengan satu hentakan lurus dan cepat. Dari uraian di atas, apakah yang terjadi pada koin uang logam tersebut?

2. Sebuah kotak bermassa $10 \mathrm{~kg}$ ditarik dengan gaya sebesar $100 \mathrm{~N}$. apabila ada gaya penghambat pada kotak sebesar $25 \mathrm{~N}$, tentukan jarak yang ditempuh kotak setelah 10 sekon!

3. Ketika anda berada dalam sebuah bis yang sedang melaju, tiba-tiba seekor sapi berjalan di depan bis dan sopir menginjak rem secara mendadak. Maka apa yang akan terjadi pada anda? Bagaimanakah anda menjelaskan kasus tersebut?

4. Sebuah bola dilemparkan vertikal ke atas dari tanah dan berada di udara selama 5 sekon. Jika percepatan gravitasi bumi $10 \mathrm{~m} / \mathrm{s}$. Berapakah kelajuan awal bola dan ketinggian maksimum yang dicapai bola tersebut?

5. Perhatikan gambar berikut!

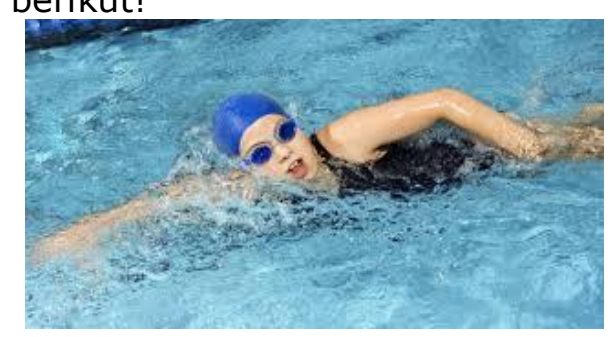

Manakah di bawah ini yang paling efektif untuk menjelaskan gambar di atas!
a. Tekanan
b. Hukum I Newton
c. hukum II Newton
d. massa jenis air
e. Hukum III Newton

6. Perhatikan gambar berikut!

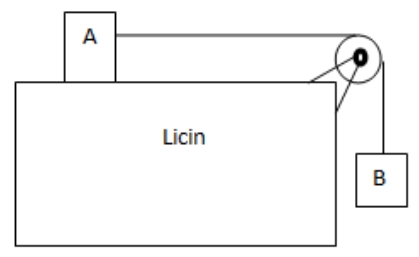

Balok A bermassa $3 \mathrm{~kg}$ dan balok B bermassa $2 \mathrm{~kg}$. Percepatan gravitasi $10 \mathrm{~m} / \mathrm{s}^{2}$. Tentukanlah besar percepatan benda dan tegangan tali! 
7. Seorang anak mendorong sebuah mobil-mobilan di lantai kasar. Koefisien kinetis antara mobil-mobilan dengan lantai adalah 0,5. Jika jarak yang ditempuh mobil-mobilan adalah 10 meter dari saat mobil-mobilan tersebut mulai melambat hingga berhenti $\left(\mathrm{g}=10 \mathrm{~m} / \mathrm{s}^{2}\right)$. Tentukan:

a. Percepatan gerak mobil-mobilan

b. Kecepatan awal mobil-mobilan sebelum pengereman

c. Waktu yang dibutuhkan untuk menempuh jarak dari mulai pengereman sampai berhenti 